\title{
NTFPs Collection as an Alternative Source of Income for Poverty Alleviation among Rural Farmers in Egbeda Local Government Oyo State
}

\author{
Yusuff, A.Q. \\ Adams, B.A. \\ Adewole, A.T. \\ Olatoke, T.I. \\ Federal College of Forestry, Ibadan, Oyo State, Nigeria \\ Email: yusadeq@yahoo.com
}

\section{Doi:10.5901/ajis.2014.v3n6p467}

\begin{abstract}
The study investigated Non-Timber Forest Products (NTFPS) collection as an alternative source of income for poverty alleviation among rural farmers in Egbeda local government of Oyo state.The local government has six(6) rural wards while five(5)wards were selected at random by balloting system and semi-structural questionnaire was administered to 80 respondents. The data collection were analysed using descriptive and inferential statistics while Gross margin model was used to calculate the cost and rate of returns of NTFPs. The results showed that males and age range 40-49years were predominate in the study.Furthermore, majority of the respondents had no formal education andalso married. The gross margin analysis per respondent per month shows that the rate of return for vegetable, fire wood,medicinal plant,charcoal,bush meat,honey,chewing stick,forest fruit were profitable business since the rate of return was greatera than 1.Moreover, poor marketing,low demand,price fluctuation, irregular supply of product and transportation are the most challenging factors facing the marketing of NTFPs in the selected area.Government can help in ameliorating these problems by helping to develop the rural area especially by providing good roads that will link our rural area and the forest so as to enhance easy transportation .In addition, people should pay more attention to these enterprise as one of the avenue to address the high rate ofunemploymentin the Egbeda local government and especially Nigeria in general.
\end{abstract}

Keywords: Poverty alleviation, Rural farmers, Gross margin analysis, Questionnaires, Unemployment.

\section{Introduction}

Wikens(1991)defined non-timber forest products(NTFPs)as all forest products other than timber that are extracted from the forest ecosystems and utilized within the household or marketed or have social,cultural or religious significance.The NTFPs, therefore refer to both tangible forest products that are gathered from the forest by local people for home use(food, fibre and forage)as well as for income generation.

Unlike timber-based products, Non-timber forest product (NTFPs) came from a large variety of plant parts and is formed into adverse set of products. As submitted by Chamberlain (1998) NTFPs contribute significantly to local and regional economics; and with the current trend in the trade and use of NTFPs, it is bound to grow substantially over the next decades. Like timber, NTFPs may further be processed into consumer oriented products. Value is added to NTFPs through processing of the products throughthe use of machines, chemicals and other means.

The indigenous people and peasant communitiesmay not have what it takes to sustainably add value to NTFPs. This is because value addition may involve huge capital which may not be easilyaccessible to the rural dwellers. But as submitted by Donovan,et. al. (2006) they have started to formSmall and Medium Forest Enterprises (SMFEs) to add value to their timber and non-timber forest products (NTFPs). Though, such enterprises credit facilities are available to aid product development, provide incentives for sound forest management, support increased value addition, and promote the formationof human, social, physical and financial capital forsustainable production of timber and NTFPs. In their own study, Peters et.al. (1989) estimated thelong term economic returns from the forests managed for Non-Timber Forest Products (NTFP) intropical forests as greater than the net returns fromtimber or conversion of forest to agricultural use. This proposition attracted many forest conservationists in favor of NTFP management. Many developing countries 
like Nigeria have initiated moves to allocate financial and human resources in the promotion of NTFP activities but there have been mixed response regarding impact of NTFP harvesting in forest environment and livelihoods.

Ruiz Pérez, and Byron (1999) were of the opinion that conservation of the world's tropical forestsdepends on finding new products, developing markets and improving marketing systems for NTFPs. Food and Agriculture Organization of United Nations (FAO,2011) and The Centre for People and Forests (RECOFTC,2011and2012) assume that communities will conserve and protect forest resources if they receive tangible benefits from sustainable forest utilization. Lynch (1995) recognized the importance of NTFPs for income generation and food security and Shiva(1995)reposed NTFPs as the "potential pillars of sustainable forestry". The importance of NTFPs notwithstanding, when compared with timber they have historically been neglected by governments particularly in Nigeria. The capacity to promote sustainable use of NTFP and facilitate increased financial benefits to localusers as incentives for forest conservation isconsequently low. This was reposed by Adepoju and Salau (2007) that gaps exist in understandingthe range of products used from forests, their taxonomic classification, socio-economic values, technical packages and the policy contexts for their sustainable use. They were also of the opinion thatpolicy development is still largely disconnected from field experiences (Adepoju and Salau, op. cit). Promoting sustainable use of NTFPs through value addition require financial input. This can be achieved through several means, one of which credit facilities plays a vital role.

World Bank (2004) defined poverty as a condition of insufficient resources or income where in its most extreme form is the lack of basic human needs such as health services, education, drinking water and so on. The distribution of extreme poverty by occupation category further revealed that agricultural and forestry contributed the highest percentage (64.7\%) of national poverty in Nigeria. These millions of small scale farmers are entrapped in self-reinforcing cycle of poverty, low income leading to low saving which in turn leads to low investment and consequent low comsumption, low health status, low productivity and eventual persistence of poverty (World Bank 1996).Social indicators which include illiteracy level, health, nutritional status, housing, water, sanitation and access to credit reveal the incidences ,depth and severity of poverty in Nigeria. These indicators are compressed into Human Development Indicators (HDI) as reported by Zanna (2000) and Salvia (2007).

Ensuring a thriving agricultural economy is critical for reducing poverty, enabling food security and managing natural resources in a sustainable fashion. Past attempt to alleviate poverty in Nigeria which yielded minimal fruit can be grouped into two distinct areas: Pre-SAP, SAP/Post SAP. Operation Feed the Nation (OFN),Free and compulsory Primary Education (FCPE), Green Revolution, Low cost Housing, River Basin Development Authority (RBDA), National Agricultural Land Development Authority (NALDA), Agricultural Development Programmes (ADP),Agricultural Credit Guarantee Scheme (ACGS),Strategies Grain Reserves Programme (SGRP),Rural Electrification Scheme (RES), and Rural Banking Programme (RBP) were all Pre-SAP Programme mostly designed to take care of employment generation, enhancing agricultural output and income, and stemming the rural-urban migration tide.SAP/Post-SAP Programme includes:Directorate for Food, Road and Rural Infrastructure (DFRRI), National Directorate of Employment (NDE),Better Life Programme (BLP),People's Bank of Nigeria (PBN), Community Banks Programme ,Family Support Programme (FSP) and Family Economic Advancement Programme (FEAP). The Obasanjo regime established the National Poverty Eradication Programme (NAPEP) in 2001, under this scheme such as Youth Empowerment Scheme (YES), Rural Infrastructure Development Scheme (RIDS), Social Welfare Services Scheme (SOWESS), Capacity Acquistion Programme (CAP), and Natural Resources Development Conservation Scheme (NRDCS) and Millennium Development Goals (MDGs)(Ali,2006).These programme were geared toward the alleviation of poverty but made little or no impact on the people due to implementation. Its,therefore, becomes pertinent to examine Non-Timber Forest Product collection as an alternative source of income for poverty allieviation among rural farmers. A case study in Egbeda local government area of Oyo state.

\section{Materials and Methods}

\subsection{Study Area}

This study area is Egbeda Local Government Area of Oyo state, Nigeria with an average population 319,388people.It is sub-divided into eleven ward and they are Erunmu, Aiyede-Alugbo, Odo Oba, Lekesumu, Ayiwogbo, Olodo, Ayepe, Wakajaye, Osegere, Alakia and Adegbayi, Olubadan and Egbeda. The town is located on latitude $7021^{\prime \prime} \mathrm{N}-8^{0} \mathrm{Nand}$ Longitude $4^{\circ} 02^{\prime \prime E ~-~ 4028 " E w i t h ~ a ~ l a n d m a s s ~ o f ~} 420.75$ square metres. (Lawal,et al.2011). 


\subsection{Sampling Procedure and Sample Size}

A structured questionnaire was administered among males and females who were involved in the extraction and marketing of NTFPs in five (5) wards out of six (6) rural wards which was purposively random sampled. These wards are Erunmu, Ajiwodo, Olodo, Osegere Awaye, Egbeda, Ayede Alugbo.

A total number of 80 questionnaires were distributedto the farmers using stratification sampling method and returned. Altogether, 20 questionnaires in Erunmu, 13 in Ajiwodo, 18 in Osegere, 14 in Egbeda and 15 questionnaires in Ayede based on the existing estimated population.

\subsection{Data Analyses}

Simple descriptive statistics such as mode, standard deviation, percentages and tables were used to describe the socio-demographic characteristics of the respondents. Gross margin analysis was used to calculate the cost and returns of NTFPs.

The following models were used to determine the profitability

Gross margin $(\pi)=$ Total revenue $(\mathrm{TR})-$ Total cost $(\mathrm{TC})$

Rate of Returns (ROR) $=\frac{\pi}{T C}$ (Yusuff, 2004) $^{2}$

In determining the constraints of NTFPs, four point likert scales was used.

To make inferential statements, the mean score was compared with the critical mean 2.5. If the calculated mean is greater than the standard critical value, the hypothesis is rejected otherwise, it is accepted (Yusuff, 2004) ${ }^{1}$.

\section{Results and Discussions}

\subsection{Socio-Economic Characteristics of the Respondent}

The table 1 below shows that most respondents were male (58.8\%), which shows that male involved in the collection of NTFP than females (Das 2005). It also identified that respondent who were between the age of 40 to 49 years (43.8\%) collect NTFP than others followed by youngsters of age $30-39$ years $(21.3 \%)$ respondents of $<30(18.8 \%)$ and $(16.3 \%)$ were 50-59 years. It also revealed that the height number of respondents were Married $70 \%, 17.5 \%$ Single and $6.3 \%$ were Divorced and Widow. The study area being a rural one, (36.3\%) of the respondents had no formal education, (30.0\%) had primary education, (27.5\%) secondary education, NCE/HND/B.Sc. (6.3\%) indicating a low level of education. This is in agreement with earlier work by Usman,et al (2006) which shows that $83.3 \%$ of Garcina kola (a NTFP) sellers in Ibadan were not having formal education. However their engagement of farm practice in the study area could be considered with the maximum years of experience of 1-19 years (68.8\%). 
Table 1: Socio-Economic Variables

\begin{tabular}{|c|c|c|c|c|}
\hline Parameter & Frequency & Percentage & Mode & Std Deviation \\
\hline \multicolumn{5}{|l|}{ Gender } \\
\hline Male & 47 & 58.8 & Male & 0.495 \\
\hline Female & 33 & 41.2 & & \\
\hline Total & 80 & 100.0 & & \\
\hline \multicolumn{5}{|l|}{ Age (years) } \\
\hline$<30$ & 15 & 18.8 & & \\
\hline $30-39$ & 17 & 21.3 & $40-49$ & 0.978 \\
\hline $40-49$ & 35 & 43.8 & & \\
\hline$>49$ & 13 & 16.3 & & \\
\hline Total & 80 & 100.0 & & \\
\hline \multicolumn{5}{|l|}{ Marital Status } \\
\hline Single & 14 & 17.5 & & \\
\hline Married & 56 & 70.0 & Married & 0.703 \\
\hline Divorced & 5 & 6.3 & & \\
\hline Widow & 5 & 6.3 & & \\
\hline Total & 80 & 100.0 & & \\
\hline \multicolumn{5}{|l|}{ Education } \\
\hline No formal & 29 & 36.3 & & \\
\hline Primary & 24 & 30.0 & No formal education & 0.947 \\
\hline Secondary & 22 & 27.5 & & \\
\hline NCE/HND/B.SC & 5 & 6.3 & & \\
\hline Total & 80 & 100.0 & & \\
\hline \multicolumn{5}{|c|}{ Number of Children } \\
\hline $1-2$ & 8 & 10.0 & & \\
\hline $3-4$ & 50 & 62.5 & 3-4 & 0.736 \\
\hline $5-6$ & 18 & 22.5 & & \\
\hline Above 6 & 4 & 5.0 & & \\
\hline Total & 80 & 100.0 & & \\
\hline \multicolumn{5}{|c|}{ Experience (Years) } \\
\hline 1-19 & 55 & 68.8 & & \\
\hline $20-39$ & 21 & 26.3 & $1-19$ & 0.488 \\
\hline $40-59$ & 1 & 1.3 & & \\
\hline Above 60 & 3 & 3.8 & & \\
\hline Total & 80 & 100.00 & & \\
\hline
\end{tabular}

Source: Field Survey, 2013

Table 2 shows the availability of the product in the study area, $46.3 \%$ of the respondents often get their NTFPs weekly, $37.5 \%$ daily, $16.3 \%$ monthly. The study shows that the products were more available weekly.

Table 2: Availability of the product

\begin{tabular}{lllll}
\hline Parameter & Frequency & Percentage & Mode & Std Deviation \\
\hline Daily & 30 & 37.5 & & \\
Weekly & 37 & 46.3 & Weekly & 0.706 \\
Monthly & 13 & 16.3 & & \\
Total & 80 & 100.0 & & \\
\hline
\end{tabular}

Source: Field Survey, 2013

Table 3 revealed that most of respondent (65.0\%), often sell their product every day, while (31.3\%) once a week, (3.8\%) once a month. 
Table 3: Selling of product

\begin{tabular}{lllll}
\hline Parameter & Frequency & Percentage & Mode & Std Deviation \\
\hline Every Day & 52 & 65.0 & & \\
nce a Week & 25 & 31.3 & Everyday & 0.562 \\
Once a Month & 3 & 3.8 & & \\
Total & 80 & 100.0 & & \\
\hline
\end{tabular}

Source: Field Survey, 2013

Table 4 shows that (38.8\%) of the farmers get their NTFPs in medium scale while (36.3\%) in small scale and $25 \%$ get theirs in large scale respectively, indicating that most of the traders were operating at medium scale level. This might be attributed the inadequate finance to operate at large scale level.

Table 4: Scale of Products

\begin{tabular}{lllll}
\hline Parameter & Frequency & Percentage & Mode & Std Deviation \\
\hline Small & 29 & 36.3 & & \\
Meduim & 31 & 38.8 & Meduim & 0.779 \\
Large & 20 & 25.0 & & \\
Total & 80 & 100.0 & & \\
\hline
\end{tabular}

Source: Field Survey, 2013

Table 5 shows that (71.3\%) of the respondent do not have any other business apart from NTFP collection while (28.8\%) of respondent have other business, This shows that majority of them (71.3\%) were operating at full time traders on the NTFPs. These findings were not too different from the finding of Miah () in the studies of 170 families in enclaves of chunati wildlife sanctuary, Bangladesh.

Table 5: Business

\begin{tabular}{lllll}
\hline Parameter & Frequency & Percentage & Mode & Std Deviation \\
\hline & & & & \\
Yes & 23 & 28.8 & & \\
No & 57 & 71.3 & No & 0.455 \\
Total & 80 & 100.0 & & \\
\hline
\end{tabular}

Source: Field Survey, 2013

Table 6 revealed that (56.3\%) of the farmers have association while (43.8\%) of the respondents do not have association in the study area. Belonging to an association will enhance access to marketing information and determination of prices was discussed during their meetings. This is in-line with Usman (2003) who found that $87 \%$ of fresh fish traders in Kogi state belong to association.

Table 6: Association

\begin{tabular}{lllll}
\hline Parameter & Frequency & Percentage & Mode & STD Deviation \\
\hline Yes & 35 & 56.3 & \multirow{2}{*}{ Yes } & 0.499 \\
No & 45 & 43.8 & & \\
Total & 80 & 100.0 & & \\
\hline
\end{tabular}

Source: Field Survey, 2013

Table 7 shows that (96.3\%) of the respondents have personal savings to finance their business, $(66.3 \%)$ get theirs through grants (21.3\%) through loan from relatives while, (3.8\%) through loan from Bank. They finance their business 
through personal savings.

Table 7: Business Finance

\begin{tabular}{lllll}
\hline Parameter & Frequency & Percentage & Mode & Std Deviation \\
\hline Personal Saving & 77 & 96.3 & & \\
Loan from Bank & 3 & 3.8 & & \\
Loan from relatives & 17 & 21.3 & Personal & 1.099 \\
Grants & 53 & 66.3 & Savings & \\
Total & 80 & 100.0 & & \\
\hline
\end{tabular}

Source: Field Survey, 2013

The table 8 below shows the summary of the gross margin analysis and the profitability of the NTFPs in Erunmu,The Profit margin for vegetable, fire wood ,medicinal plant, charcoal, Bushmeat, Honey, chewingstick, forestfruit, were 13050, 1550, 4500, 40499.75, 22799.70, 24799.55, 5280.38, 3144.6 respectively. The rate of return for vegetable, fire wood, medicinal plant, charcoal ,Bush meat, Honey, Chewing stick, Forest fruit were 1.903114, 1.223022,1.818182, 2.173897, $1.878591,1.494011,1.172827,1.192975$,The results shows that for Erunmu the ROR for the selected NTFPs were greater than 1 meaning that the trading business of NTFPs were profitable business.

Table 8: Gross margin analysis per respondent per month for Erunmu

\begin{tabular}{lllll}
\hline NTFPS & Cost price(N) & Selling price(N) & Profit margin(N) & Rate of Return (ROR) \\
\hline Vegetable & 14450 & 27500 & 13050 & 1.903114 \\
Fire wood & 6950 & 8500 & 1550 & 1.223022 \\
Medicinal plant & 5500 & 10000 & 4500 & 1.818182 \\
Charcoal & 34500.25 & 75000 & 40499.75 & 2.173897 \\
Bush meat & 25950.30 & 48750 & 22799.70 & 1.878591 \\
Honey & 50200.45 & 75000 & 24799.55 & 1.494011 \\
Chewing stick & 30552.95 & 35833.33 & 5280.38 & 1.172827 \\
Forest fruit & 16295.40 & 19440 & 3144.6 & 1.192975 \\
\hline
\end{tabular}

The table 9 below shows the summary of the gross margin analysis and profitability of the NTFPs in Ajiwogbo. The profit margin for vegetable, fire wood, medicinal plant, charcoal, Bush meat was 2299.55, 2097.8, 2124.7, 3769.59, and 3199.6 respectively. The rate of return for vegetable, fire wood, medicinal plant, charcoal, Bush meat were 1.151282, 1.162592, $1.738949,1.313338,1.140331$ respectively, It is a profitable venture.

Table 9: Gross margin analysis per respondent per month for Ajiwogbo

\begin{tabular}{lllll}
\hline NTFPS & Cost of price $(\mathbf{N})$ & Selling price(N) & Profit margin(N) & Rate of Return (ROR) \\
\hline Vegetable & 15200.45 & 17500 & 2299.55 & 1.151282 \\
Fire wood & 12902.20 & 15000 & 2097.8 & 1.162592 \\
Medicinal plant & 2875.30 & 5000 & 2124.7 & 1.738949 \\
Charcoal & 12030.41 & 15800 & 3769.59 & 1.313338 \\
Bush meat & 22800.40 & 26000 & 3199.6 & 1.140331 \\
\hline
\end{tabular}

The table 10 shows the summary of the Gross margin analysis and the profitability of the NTFPs in Egbeda. The profit margin for vegetable, medicinal plant, Bush meat, Honey, Forest 'fruit were 3302.99, 1869.6, 1305, 19879.7, 28449.89. The rate of return for vegetable, medicinal plant, Bush meat, Honey, Forest fruit were 1.117836, 1.364416, 1.12061, $1.66001,1.399016$ respectively, Hence, Honey is the most profitable one among the selected NTFPs in area. 
Table 10: Gross margin analysis per respondent per month for Egbeda

\begin{tabular}{lllll}
\hline NTFPS & Cost price(N) & Selling price(N) & Profit margin(N) & Rate of Returns (ROR) \\
\hline Vegetable & 28030.31 & 31333.3 & 3302.99 & 1.117836 \\
Medicinal plant & 5130.40 & 7000 & 1869.6 & 1.364416 \\
Bush meat & 10820.00 & 12125 & 1305 & 1.12061 \\
Honey & 30120.30 & 50000 & 19879.7 & 1.66001 \\
Forest fruit & 71300.11 & 99750 & 28449.89 & 1.399016 \\
\hline
\end{tabular}

The table 11 shows the summary of the Gross margin analysis and the profitability of the NTFPs in Osegere. The profit margin for vegetable, fire wood, medicinal plant, charcoal, Bush meat, Honey, Chewing stick, Forest fruit were $3369.59,1970.3,2960,3324.85,3550,10241,1680,2699.75$.The rate of return for vegetable, fire wood, medicinal plant, charcoal, Bush meat, Honey, Chewing stick, Forest fruit, were 1.656788, 1.488908,1.397315, 1.20878, 1.25, 1.518987, $1.923077,1.224041$. Hence Chewing stick is the most profitable among the selected NTFPs in the area.

Table 11: Gross margin analysis per respondent per month for Osegere

\begin{tabular}{lllll}
\hline NTFPS & Cost price (N) & Selling price (N) & Profit margin (N) & Rate of Returns (ROR) \\
\hline Vegetable & 5130.41 & 8500 & 3369.59 & 1.656788 \\
Fire wood & 4029.80 & 6000 & 1970.2 & 1.488908 \\
Medicinal plant & 7450.00 & 10410 & 2960 & 1.397315 \\
Charcoal & 15925.15 & 19250 & 3324.85 & 1.20878 \\
Bush meat & 14200.00 & 17750 & 3550 & 1.25 \\
Honey & 19750.00 & 30000 & 10241 & 1.518987 \\
Chewing stick & 1820.00 & 3500 & 1680 & 1.923077 \\
Forest fruit & 12050.25 & 14750 & 2699.75 & 1.224041 \\
\hline
\end{tabular}

The table 12 shows the summary of the Gross margin analysis and the profitability of the NTFPs in Ayede. The profit margin for vegetable, fire wood, medicinal plant, charcoal, Honey, Forest fruit were 3752.98, 3608.18, 2110, 14859.55, 2099.75, 1199.75. The rate of return for vegetable, fire wood ,medicinal plant, charcoal, Honey, Forest fruit were $1.856776,2.233503,2.416107,1.702897,2.272383,1.666435$. Hence Medicinal plant is more profitable in Ayede.

Table 12: Gross margin analysis per respondent per month for Ayede

\begin{tabular}{lllll}
\hline NTFPS & Cost price (N) & Selling price (N) & Profit margin (N) & Rate of Returns (ROR) \\
\hline Vegetable & 4380.35 & 8133.33 & 3752.98 & 1.856776 \\
Fire wood & 2925.15 & 6533.33 & 3608.18 & 2.233503 \\
Medicinal plant & 1490.00 & 3600 & 2110 & 2.416107 \\
Charcoal & 21140.45 & 36000 & 14859.55 & 1.702897 \\
Honey & 1650.25 & 3750 & 2099.75 & 2.272383 \\
Forest fruit & 1800.25 & 3000 & 1199.75 & 1.666435 \\
\hline
\end{tabular}

The table 13 below shows the constraints of the study Area, The mean constraints for poor marketing, low demand, price flunctuation, transportation, and irregular supply of product were 2.95, 2.84, 2.99, 3.19, 2.59. Hence, transportation has the highest and the most challenging factors facing the marketing of NTFPs in the selected area.

\begin{tabular}{llllllll}
\hline S/N & Challenges & SA & A & U & D & Mean & Remark \\
& & $\mathbf{4}$ & $\mathbf{3}$ & $\mathbf{2}$ & $\mathbf{1}$ & & \\
\hline 1 & Poor marketing & 22 & 39 & 12 & 7 & 2.95 & A challenge \\
2 & Low demand & 14 & 46 & 13 & 7 & 2.84 & A challenge \\
3 & Price fluctuation & 10 & 61 & 7 & 2 & 2.99 & A challenge \\
4 & Transportation & 28 & 42 & 7 & 3 & 3.19 & A challenge \\
5 & Irregular supply of product & 7 & 42 & 22 & 9 & 2.59 & A challenge \\
\hline
\end{tabular}




\section{Conclusion}

The study shows that NTFPs collection was profitable business, as shown in the result of the value of gross profit and rate of return. This shows that the business is both feasible and viable. Engagement of NTFPs in the study area was found to be gender skewed with those involved not having access to loan despite its lucrative nature.

\section{Recommendations}

Based on the findings so far, NTFPs extraction in the study area can serve as an alternative source of income. It is therefore recommended that:

- People should pay more attention to the enterprise as one of the avenue to address the high rate of unemployment in the rural areas.

- Government should assist in giving soft loans to individual or co-operative who are involved in the business.

- Government should provide good road that will link our rural areas and the forest so as to enhance easy transportation.

- Government should provide adult education to the farmers so as to enhance their education thereby increasing their access to information with regards to their business of NTFPs extraction/production. This will go a long way in assisting them to adopt new innovations.

\section{References}

Adepoju, A. A. and Salau, A. S. (2007): Economic Valuation of Non-Timber Forest Products (NTFPs) MPRA paper 2689

Ali, G. (2006): Alleviating Poverty in Northern Nigeria. A paper presented at the Annual Convention of Zumunta Association, USA Minneapolis, MN July $28-29,2006$

Chamberlain, D. B. (1998): Sustainable use of non-traditional forest product - Alternative Forest Based Income Opportunities. In Jonathan, S. K. (ed.) proceeding of Conference on Natural Resources Income Opportunities on Private Land. April 5 - 7, 1998 in Hagerston, Mary. Pp. 14-147K.

Das, B. (2005): Role of NTFPs among Forest Villagers in a Protected Area of West Bengal. Journal of Human Ecology, 18(2): 129-136

Donovan, J., Stoian, D., Macqueen, J. and Grouwels S. (2006): The business side of sustainable forest management: small and medium forest enterprise development for poverty reduction. ODI Natural Resources Perspectives No. 104 London, UK, Overseas Development Institute. Pp. 63-72

Food and Agriculture Organization of United Nation (2011): Bangkok. Miah, R (undated):Non-Timber Forest Products and Co-management: A Case Study of Chunati Wildlife Sanctuary. In Making Conservation Work: Linking Rural Livelihoods and Protected Areas in Bangladesh, Pp. 50-65

Lawal O. U. and Fagbohun, E. D. (2011): Effect of storage on nutrient composition and mycobiota of sundried soya bean. African Journal of Food Sciences, Vol. 5, no 8. Pp. 473-477

Lynch, O. J. (1995): Involving Local People in the Management and Harvesting on Non-Wood Forest Products, in Durst, P. B and Bishop, A (Eds.), Beyond Timber: Social, Economic and Cultural Dimensions of Non-Wood Forest Products in Asia and the Pacific. Proceedings of a Regional Expert Consultation held in Bangkok November 28 to December 21994.

Miah, R (undated):Non-Timber Forest Products and Co-management: A Case Study of Chunati Wildlife Sanctuary. In Making Conservation Work: Linking Rural Livelihoods and Protected Areas in Bangladesh, Pp. 50-56.

Peters, C. M., Gentry A. H. and Mendelsohn. (1989): Valuation of an Amazonian rain forest. Nature 339:655-656

RECOFTC (2011): Forest Tenure in Asia Status and Trends, RECOFTC - The Center for People and Forests. Retrieved 06/07/2012

RECOFTC (2012): Challenges for Thailand - Issues ahead for expanding community forestry in Thailand. Retrieved 06/07/2012

Ruiz Perez, M. and Byron, N. (1999): a methodology to analyze divergent case studies of non-timber forest products and their development potential. Forest Science, 45 (1):1-14.

Salvia, H. W. (2007): Analysis of poverty and inequality among small scale farmers in Hong Local Government area of Adamawa State. Unpublished M.Sc Thesis, Dept of Agricultural Economics and Extension, Federal University of Technology Yola, Nigeria.

Shiva, M. P. (1995): Collection, Utilization and Marketing of Medicinal plants from forests of India. In: Beyond Timber: Social Economic and Cultural Dimensions of Non wood Forest Products in Asia and the Pacific.

Usman J. M. (2003): Fresh fish marketing in urban areas of Kogi State: An Application of the Structure, Conducted Performance Paradigm. Unpublished M.Sc Project submitted to Department of Agricultural Economics, University of Ibadan, Ibadan.

Usman J. M., Oluyole K. A, Egbewole Z. T. and Adebisi-Adelani, O (2006): Marketing Analysis of Garigria kola (Bitter cola) in some selected market in Ibadan. In Technology and Agricultural Development in Nigeria. Proceeding of the $20^{\text {th }}$ Annual National Conference of Farm Management Association of Nigeria. Ed. Adepoju S. O and Okuneye P.B. Pp. 433-436.

World Bank (1996): Poverty Amidst Plenty: Nigeria's Poverty assessment Washington D. C

World Bank (2004): Millennium Development Goals. The World Bank Group Washington D.C

Yusuff, A.Q. (2004)1: Management Statistics for Behavioural Sciences. Onilex Global Enterprises, Ibadan.

Yusuff, A.Q. (2004)2: Mathematics for Management Studies. Onilex Global Enterprises, Mokola, Ibadan.

Zanna, B. G. (2000): The Status of Poverty Alleviation in Nigeria. A paper presented at the Annual Conference of NERA, University of Nigeria, Nsuka: Pp.1-3. 